\title{
Deforming mandibular osteomyelitis in a cow caused by Trueperella pyogenes
}

\author{
Osteomielite mandibular deformante em vaca causada por Trueperella pyogenes
}

\author{
Karen Antas Caffaro ${ }^{I}$ Carlos Alberto Hussni' ${ }^{I I}$ Rafaela Mastrangelo Risseti ${ }^{\mathrm{I}}$ \\ Daniel Queiroz França ${ }^{I I}$ Marília Masello Junqueira Franco ${ }^{I}$ \\ Vânia Maria de Vasconcelos Machado ${ }^{\text {III }}$ Alexandra Frey Belotta ${ }^{\text {III }}$ Antonio Carlos Paes \\ Gustavo Henrique Batista Lara ${ }^{I}$ Amanda Bonalume Cordeiro de Morais ${ }^{\mathrm{I}}$ \\ Fernando José Paganini Listoni ${ }^{\mathrm{I}}$ Marcio Garcia Ribeiro ${ }^{*}$
}

ABSTRACT

This study reports an unusual case of deforming mandibular osteomyelitis in a cow caused by Trueperella (Arcanobacterium) pyogenes, on the face of the ventrolateral caudal portion of the right branch of the mandible. Fragment aspired oflesion by fine needle allowed cytological characterization, isolation and identification of $\boldsymbol{T}$. pyogenes. Radiographic examination showed marked periosteal reaction in the right mandible, numerous lytic areas and cortical bone destruction. Despite of treatment based on in vitro antimicrobial sensitivity test, it was recommended the euthanasia due to progressive worsening of the cow's condition. Multiple abscesses were observed in the mandibular region at necropsy. Pyogranuloma was characterized in histological exam. Sampled material collected from the lesion after necropsy resulted in microbiological reisolation of $\boldsymbol{T}$. pyogenes.

Key words: bovine, Trueperella pyogenes, Arcanobacterium pyogenes, osteomyelitis, jaw.

\section{RESUMO}

Relata-se caso incomum de osteomielite mandibular deformante em vaca, causada por Trueperella (Arcanobacterium) pyogenes, na face ventro-lateral da porção caudal do ramo direito da mandíbula. A punção aspirativa de fragmento da lesão permitiu a caracterização citológica, o isolamento microbiano e identificação de $\boldsymbol{T}$. pyogenes. Exame radiográfico mostrou acentuada reação periodontal na mandíbula direita, com predomínio de áreas líticas e destruição da cortical óssea. Apesar da instituição do tratamento baseado no teste de sensibilidade microbiana in vitro, foi recomendada a eutanásia, em virtude da piora progressiva do estado geral do animal. No exame post-mortem foram observados múltiplos abscessos na lesão que, histologicamente, foi caracterizada como piogranuloma. A colheita de material da região mandibular afetada, após a necropsia, resultou no reisolamento microbiológico de $\boldsymbol{T}$. pyogenes.

Palavras-chave: bovino, Trueperella pyogenes, A. pyogenes, osteomielite mandibular.

Trueperella (Arcanobacterium) pyogenes is a gram-positive opportunistic bacterium, belonging to the group of actinomycetes (QUINN et al., 1994). Recently, based on phenotypic and molecular techniques the former Arcanobacterium pyogenes was reclassified as Trueperella pyogenes (YASSIN et al., 2011). T. pyogenes has ubiquitous distribution, and usually is found in the bacterial microflora of skin, oropharynx and intestinal tract of animals. It is found also in contaminated utensils, or matter, carried by flies leading to "summer mastitis" in cows (MOTTA et al., 2011). Several pyogenic clinical manifestations are caused by $\boldsymbol{T}$. pyogenes in livestock, such as pneumonia, arthritis, lymphadenitis, peritonitis, umbilical infections, arthritis, urinary tract infections, dermatitis, metritis, mastitis, endocarditis, pneumonia, and abscesses in organs (RADOSTITS et al., 2007). Rarely $\boldsymbol{T}$. pyogenes is described as an etiological agent of osteomyelitis in livestock (CURCIO et al., 2002). Osteomyelitis is characterized as inflammation of bone with involvement of the medullar cavity (MCGAVIN \& ZACHARY, 2007). Bone infections caused by $T$. pyogenes occur mainly by hematogenous spread, predominantly in young animals. T. pyogenes

IDepartamento de Higiene Veterinária e Saúde Pública, Faculdade de Medicina Veterinária e Zootecnia (FMVZ), Universidade Estadual Paulista "Júlio de Mesquita Filho" (UNESP), CP 560, 18618-970, Botucatu, SP, Brasil. E-mail: mgribeiro@fmvz.unesp.br.*Autor para correspondência.

IIDepartamento de Cirurgia e Anestesiologia Veterinária, FMVZ, UNESP, Botucatu, SP, Brasil.

IIIDepartamento de Reprodução Animal e Radiologia Veterinária, FMVZ, UNESP, Botucatu, SP, Brasil. Received 03.11.14 Approved 04.10.14 Returned by the author 08.01.14 CR-2014-0370.R1 
may also infect bone tissue secondary to inoculation by sharp objects, eating dry grass or cactus plants, umbilical infections, periodontitis, or by contamination on surgical procedures, such as fixing intrabony pins (RADOSTITS et al., 2007).

In domestic ruminants, osteomyelitis usually lead to chronic lesions characterized by pyogranulomatous process, necrosis and bone tissue destruction, and poor response to treatment with conventional antimicrobials (MCGAVIN \& ZACHARY, 2007). Actinomyces bovis and Nocardia spp., and less frequently Escherichia coli, Streptococcus sp. and Staphylococcus sp. are the most frequent microorganisms isolated from osteomyelitis in livestock. Jaw infections caused by $\boldsymbol{T}$. pyogenes in domestic ruminants difficult mastication of food, resulting in signs of emaciation, weight loss, dysphagia and salivation. Periodontal infections by $\boldsymbol{T}$. pyogenes have been described in calves kept on pasture in Brazil, in recently cleared areas (RADOSTITS et al., 2007).

It was admitted at the Veterinary Hospital of UNESP/Botucatu, SP, Brazil, Holstein crossbreed cow, five years old, with history of progressive swelling in the jaw a one year before, with weight loss and reduction in milk production. The owner reported also abscesses in jaw, around five months before arrival at veterinary hospital, without remission of clinical signs. The cow was kept on pastures of low quality due to the recent drought in the region. At clinical examination it was observed fever, decreased ruminal movements and mandibular swelling, more pronounced in the ventral-lateral face of caudal portion on the right horizontal branch of jaw (Figure 1). At palpation, the lesion was firm and not painful. Hematological exams revealed leukocytosis, neutrophilia, and moderate anemia.

Lateral, lateral oblique and dorso-ventral radiographic views were performed. Severe periosteal reaction in the caudal portion of the right mandible, with numerous lytic areas and destruction of cortical bone was observed (Figure 2). Areas of osteopenia in the transition between the vertical and horizontal branch of the right mandible, and marked soft tissue swelling were also observed, compatible with severe osteomyelitis. Fragments of the lesion were collected by fine needle aspiration and submitted to Panoptico and Gram staining (RIBEIRO et al., 2011), and microbiological culture. The samples were plated simultaneously on defibrinated sheep blood agar (5\%) incubated aerobically, with $5 \% \mathrm{CO}_{2}$, and in anaerobic conditions, at $37^{\circ} \mathrm{C}$ for 96 hours. The same samples were also subjected to MacConkey and Sabouraud dextrose medium, maintained under the same aerobic conditions described above. After 48 hours, pure isolation of small colonies, with $1 \mathrm{~mm}$ in diameter, beta-haemolytic on sheep blood agar under aerobic and $5.0 \% \mathrm{CO}_{2}$ was observed, suggestive of $\boldsymbol{T}$. pyogenes. Panoptic, Giemsa, and Gram staining revealed small pleomorphic microorganisms ("coryneform" aspect). The isolate was submitted to CAMP test with $\boldsymbol{S}$. aureus ATCC 13565, showing positive result, and also

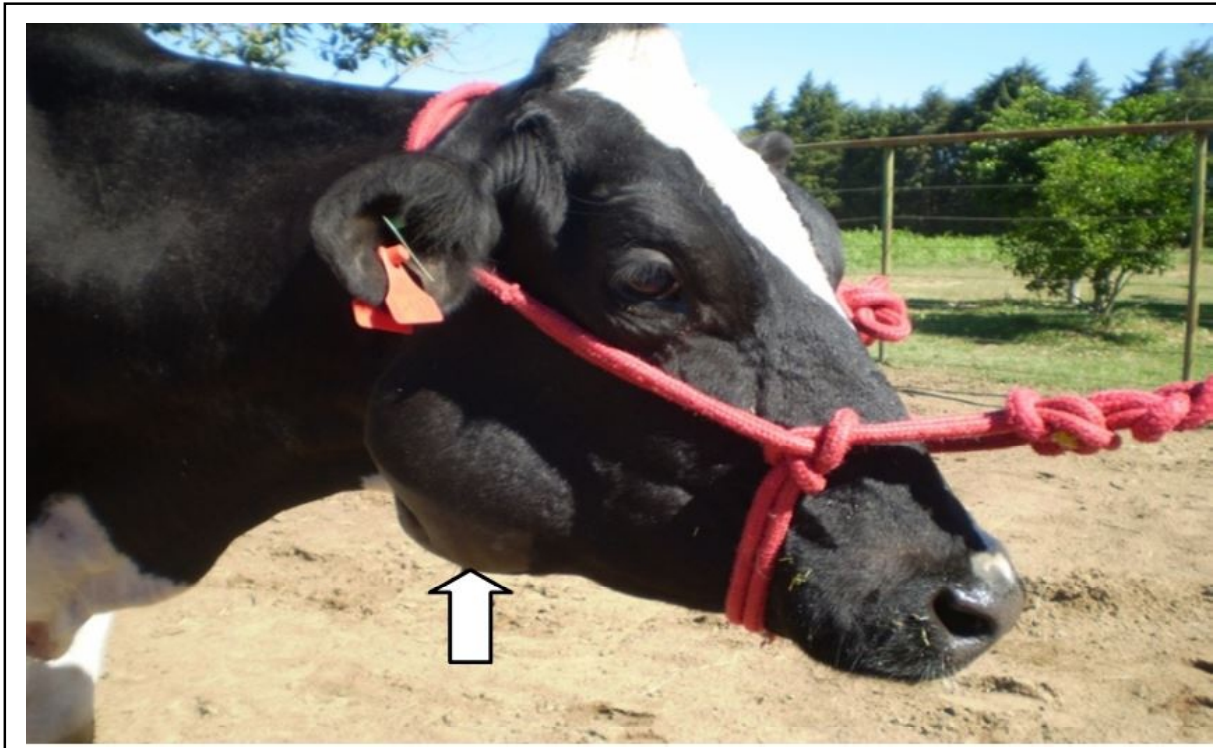

Figure 1 - Mandibular swelling most pronounced in the ventral-lateral face of the caudal portion on the right horizontal branch of jaw (arrow), in a cow caused by Trueperella pyogenes. 


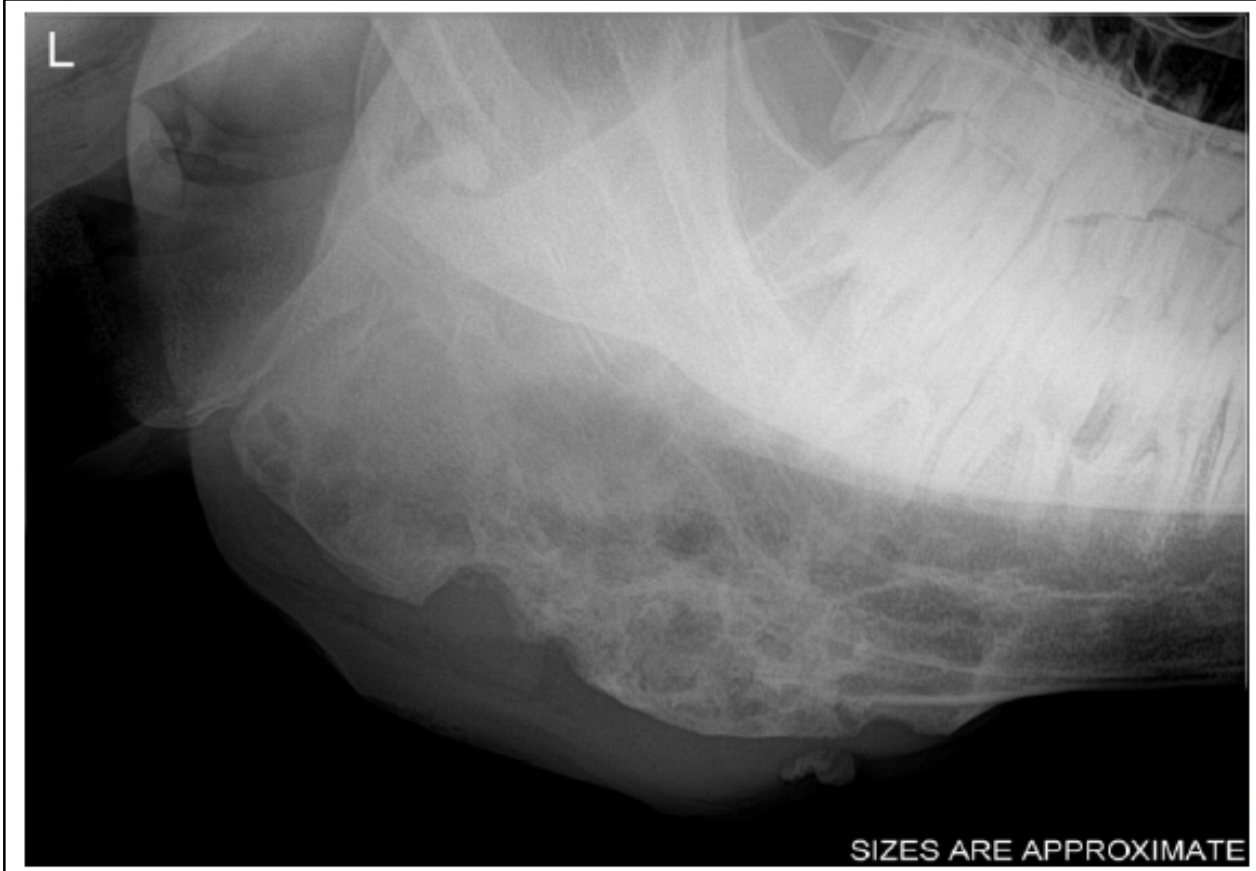

Figure 2 - Radiographic image of skull on lateral oblique projection isolating right horizontal branch of jaw in a cow, caused by Trueperella pyogenes: severe irregular periosteal reaction in the caudal portion of mandible, associated to predominantly lytic areas and destruction of cortical bone was observed, suggestive of osteomyelitis.

subjected to different phenotypic tests and substrate utilization, which allowed classification of $T$. pyogenes (QUINN et al., 2011).

The isolate was submitted to in vitro antimicrobial disk susceptibility test (CLSI, 2012) modified by addition of sheep blood $(5.0 \%)$ and tween $80(0.5 \%)$, and showed susceptibility to penicillin $\mathrm{G}$, tetracycline, ceftiofur, florfenicol, rifampicin, enrofloxacin, gentamicin, amikacin, ceftriaxone, ampicillin, doxycycline and amoxicillin/clavulanic acid. Despite antimicrobial therapy based on the in vitro susceptibility test, combined with support therapy, euthanasia was recommended after 15 days of hospitalization, due to progressive worsening of the animal body condition.

Multiple abscesses in the mandibular region affected were observed at post-mortem examination. Fragment of lesion was submitted to histological examination ( $\mathrm{H} \& \mathrm{E}$ and Giemsa stains). Histologically, the lesion was characterized by multifocal areas of pyogranulomas, with bone lytic areas, infiltrated predominantly by neutrophils, epithelioids and macrophages cells, and presence of "coryneform" organisms, surrounded by a fibrous tissue. No "sulphur granules" were observed, which is a characteristic of Actinomyces bovis infections.
A fragment of approximately $2 \mathrm{~cm}$ was collected in the transverse plane of skull, right in the damaged area, and newly submitted to same microbiological culture conditions, resulting in pure re-isolation of $\boldsymbol{T}$. pyogenes.

Rarely $\boldsymbol{T}$. pyogenes has been reported in the etiology of osteomyelitis in cattle (CURCIO et al., 2002). Actinomyces bovis and Nocardia spp. have been the most frequent agents isolated in bovine osteomyelitis (RADOSTITS et al., 2007). The routine diagnosis of $\boldsymbol{T}$. pyogenes infections in domestic animals is based on microbial culture, phenotypic classification of microorganism, cytology and histopathology exams (RADOSTITS et al., 2007; QUINN et al., 2011). Currently, molecular identification by PCR has been performed (YASSIN et al., 2011). In the animal examined, diagnosis was based on cytology, histology and microbiological culture, reinforcing that combination of methods improves the diagnosis of $\boldsymbol{T}$. pyogenes. In addition, differential phenotypic diagnosis was performed against other bovine mandibular ostemyelitis causes, particularly Actinomyces bovis. Besides the same possible clinical condition, $A$. bovis is characterized by branching filaments organisms, isolated in anaerobic conditions and typically non-haemolytic. In contrast, T. pyogenes have a "coryneform" aspect, 
is isolated in aerobic and/or $5 \% \mathrm{CO}_{2}$ requirements, and produces haemolysis in sheep blood agar (QUINN et al., 2011). T. pyogenes infections are characterized by an opportunistic behavior in livestock (RADOSTITS et al., 2007). However, microbiological isolation and phenotypic identification of $\boldsymbol{T}$. pyogenes from lesion fragments, as well as presence of pleomorphic ("coryneform") organism causing pyogranulomatous lesion in histopathological examination, compatible with this actinomycete, enable to confirm $T$. pyogenes as a primary cause of mandibular osteomyelitis in the studied cow.

Oral cavity infections of cattle caused by T. pyogenes are attributed to traumatic inoculation of the bacterium by sharp objects, fibrous foods, cactus plants, or secondary to processes of periodontitis, umbilical infections, as well as contamination on surgical procedures (RADOSTITS et al., 2007). In the present report, evident signs of lesions in the oral cavity were not found, neither the presence of sharp or foreign objects, as well periodontal inflammation in the jaw. Thus, T. pyogenes infection may have been caused by small fissures caused by fibrous food, and favors the multiplication of agent present in the microflora of oropharyngeal cavity. Although the treatment was based on in vitro antimicrobial susceptibility test, $\boldsymbol{T}$. pyogenes commonly is refractory to conventional therapy, especially in bone infections. The failure of treatment in $T$. pyogenes infections in livestock have been attributed to formation of pyogranulomas, intracellular location of bacterium, and limitation of conventional drugs to reach therapeutic concentrations inside lesions (RADOSTITS et al., 2007). There are no specific measures to prevent $\boldsymbol{T}$. pyogenes infections in livestock. Nevertheless, anti-septic cares of navel on calves, proper hygiene and anti-septic cares on surgical procedures, removal of sharp objects from pastures, special cares on peri-partum of cows, prevent feeding with dry or abrasive forage, and control of flies are procedures that might reduce the occurrence of $\boldsymbol{T}$. pyogenes infections in livestock.

\section{ACKNOWLEDGEMENTS}

We appreciate the financial support of São Paulo Research Foundation (FAPESP) (Grant 2013/17293-0).

\section{REFERENCES}

CLINICAL AND LABORATORY STANDARDS INSTITUTE. Performance standards for antimicrobial susceptibility testing (CLSI-NCCLS). Wayne, PA, USA, 2012. V.32.

CURCIO, B.R. et al. Isolamento de Arcanobacterium pyogenes de granuloma actinomicóide em bovino. Ciencia Rural, v.32, n.5, p.885-889, 2002. Available from: <http://www.scielo.br/ scielo.php?script=sci_arttext \&pid=S0103-84782002000500023>. Accessed:May20,2014.doi: 10.1590/S0103-84782002000500023.

MCGAVIN, M.D.; ZACHARY, J.F. Pathologic basis of veterinary diseases. 4.ed. Missouri, USA: Mosby Elsevier, 2007. 1476p.

MOTTA, R.G. et al. Surto de mastite bovina causada por Arcanobacterium pyogenes. Arquivo Brasileiro de Medicina Veterinária e Zootecnia, v.63, n.3, p.736-740, 2011. Available from: <http://www.scielo.br/scielo.php?script=sci_arttext\&p $\mathrm{id}=$ S0102-09352011000300027>. Accessed: May 20, 2014. doi: 10.1590/S0102-09352011000300027.

QUINN, P.J. et al. Veterinary microbiology and microbial disease. 1.ed. Wolfe Publishing, 1994. 648p.

QUINN, P.J. et al. Veterinary microbiology and microbial disease. 2.ed. UK: Wiley-Blackwell, 2011. 1231p.

RADOSTITS, O.M. et al. (Eds). Veterinary medicine: a textbook of the diseases of cattle, horses, sheep, pigs, and goats. 10.ed. Philadelphia: Saunders, 2007. 2156p.

RIBEIRO, M.G. et al. Citologia aspirativa no diagnostico da linfadenite em ovinos. Pesquisa Veterinária Brasileira, v.31, n.10, p.839-843, 2011. Available from: <http://www.scielo.br/ scielo.php?pid=S0100-736X2011001000002\&script=sci_arttext $>$. Accessed: May 20, 2014. doi: 10.1590/S0100-736X2011001000002.

YASSIN, A.F. Comparative chemotaxonomic and phylogenetic studies on the genus Arcanobacterium Collins et al. 1982 emend. Lehnen et al. 2006: proposal for Trueperella gen. nov. and emended description of the genus Arcanobacterium. International Journal of Systematic and Evolutionary Microbiology, v.61, p.1265-1274, 2011. Available from: <http://www.ncbi.nlm.nih. gov/pubmed/20622055>. Accessed: May 20, 2014. doi: 10.1099/ ijs.0.020032-0. 